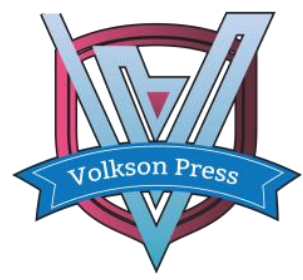

\title{
The Impact of Online Promotions on Online Impulsive Buying Behavior: Mediating Effects of Perceived Value, Positive Emotion, and Moderating Effects of Online Reviews
}

\author{
Chiang-Kuo Tu${ }^{1}$, Kuan-Wei $\mathrm{Wu}^{2 *}$, Chii-Huei Jean ${ }^{3}$ and Yue Huang ${ }^{4}$ \\ ${ }^{1234}$ China-ASEAN International College, Dhurakij Pundit University, Thailand \\ *email: kuan-wei.wu@dpu.ac.th \\ This is an open access article distributed under the Creative Commons Attribution License, which permits unrestricted use, distribution, and reproduction in any \\ medium, provided the original work is properly cited.
}

\section{ARTICLE DETAILS}

\section{Article History:}

Received 02 october 2017 Accepted 06 october 2017 Available online 11 october 2017

\section{Keywords:}

Online Promotions; Online Impulsive Buying Behavior; Perceived Value; Positive Emotion; Online Reviews.

\section{ABSTRACT}

The expansion of China's online shopping market has built a new business online promotion model and changed the online shoppers' consumption behavior. There was little research done concerning the impact of promotions on impulsive buying behavior and exploring the mediating effects of perceived value and positive emotion and the moderating effect of online reviews, in the context of online promotions of China. The data were collected from 330 individuals in China, providing their online shopping experience for the proposed research model. The conclusions showed that online promotions positively impacted on online impulsive buying behavior. Perceived value and positive emotion played a mediating role between online promotions and online impulsive buying behavior respectively, but online reviews didn't play a moderating role. These findings are expected to help online shopping enterprises design their online promotions programs.

\section{Introduction}

According to the China Internet Network Information Center (CNNIC) Statistical Reports (2017), China had 467 million online shoppers, a 12.9\% of increase in 2015, where 441 million were mobile online shoppers, a $29.8 \%$ of increase in 2015 . The data above-mentioned show that the rapid growth of online shopping users provides a huge potential market. Having noticed such a trend, more and more companies use a variety of online shopping promotions strategies to gain more customers and increase the sales. China's online shopping development, it's often been seen that online promotions activities, such as "6.18 Online Shopping Festival" and "Double 11 (China Largest Online Shopping Day)", prompting many consumers following the stimulation emotions to consume a great deal. Before consumers make such a purchase, they may not have a purchase plan, and online impulsive buying behavior is indeed increasing the sales of many commodities. After reviewing the literature about online promotions affecting online impulsive buying behavior (Lai, 2017; Madhavaram \& Laverie, 2004), we found that hardly perceived value or positive emotions were discussed as mediating variable, and online reviews were little discussed as moderating variable either to examine the above-mentioned relationship. To fill this literature gap, this study is focused on this issue.

\section{Literature Review and Research Hypotheses}

\subsection{Online Promotions and Online Impulsive Buying Behavior}

According to the works of Chan (1996) and Campbell and Diamond (1990), this study classified four online promotion forms: "Price Discounts; Buy More Save More; Discount Coupon; Flash Sale". With stimulation from the online promotions information, the customers improve their perception ability of products, further leading to their impulsive purchasing behavior (Madhavaram \& Laverie, 2004). Therefore, the following hypothesis is proposed: H1. Online promotions positively affect online impulsive buying behavior.

\subsection{Mediating Effect of Perceived Value}

Online promotions are one of the important factors in improving the perceived value of consumers (Mathwick et al., 2002; Park and Lennon,
2009). Jeffrey and Hodge (2007) pointed out that under external stimuli, the consumers presented perceived impulsive buying behavior, often accompanied with emotional and cognitive responses. Businesses using online promotions to attract consumers, consumers are satisfied in the psychological need, further delivering the impulsive buying behavior. Therefore, the following hypothesis is proposed: H2. The impact of online promotions on online impulsive buying behavior will be mediated by perceived value.

\subsection{Mediating Effect of Positive Emotion}

Swinyard (1993) suggested that consumers with better emotional status would have more aggressive shopping behavior than those with worse emotional state. Beatty and Ferrell (1998) showed that consumers' impulsive buying behavior would be affected by their emotional state or mood. Thus, the following hypothesis is proposed: H3. The impact of online promotions on online impulsive buying behavior will be mediated by positive emotion.

\subsection{Moderating Effect of Online Reviews}

Park and Kim (2008) believed that the number of online reviews reflects indirectly the popularity of goods and have the confidence on their decision-making. Park et al. (2007) argued that the quality of online reviews has a positive effect on consumers' purchasing intention. Thus, the following hypothesis is proposed: H4. Online reviews moderate the effect of online promotions on online impulsive buying behavior.

\section{Research Methodology}

\subsection{Research Mode}

Based on the literature, this study proposed the research model, as shown in Figure.1. 


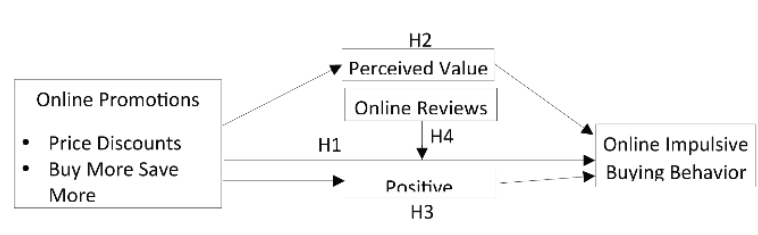

Figure. 1: Research Model

\subsection{Sampling and Data Collection}

The questionnaires were collected during the period of September to October in 2016 in the way of network or on-site survey. There are 330 valid responses, after screened for outliers and missing data. The valid response rate is $91.7 \%$. According to the responses, age between 20-30 years old was $76.1 \%$, occupation as students was $82.7 \%$, monthly shopping expense over $1,000 \mathrm{RMB}$ is $94.8 \%$, and monthly online shopping frequency over twice is $80.3 \%$. The results showed that the sampling respondents were experienced online shoppers. The sampling characteristics are in line with the requirements of this study.

\subsection{Measures}

In this research, variables are measured with five-point scale. Online promotions measured by 3 items scale adapted from Chan (1996) and referred to Campbell and Diamond (1990) to classify online promotions into 4 forms. Cronbach's $\alpha$ value were $0.842,0.837,0.831,0.838$. Online impulsive buying behavior measured by 4 items scale adapted by the work of Madhavaram and Laverie (2004). Cronbach's $\alpha$ value was 0.853 . Perceived value measured by 5 items scale adapted from Oh (2000) and Mathwick et al. (2002). Cronbach's $\alpha$ value was 0.849. Positive emotion measured by 5 items scale adapted from Yoo et al. (1998). Cronbach's $\alpha$ value was 0.846 . The construct of Online reviews comprised three dimensions, including the number of reviews (4 items) adapted from Park and Kim (2008), the quality of reviews (4 items) adapted from Park et al. (2007), and reviewer's expertise (3 items) adapted from Bansal and Voyer (2000). Cronbach's $\alpha$ value was 0.848 .

\section{Data Analysis and Results}

\subsection{Confirmatory Factor Analysis}

The indexes obtained from CFA, which indicated an acceptable model fit $\left(\chi^{2}=1584.7\right.$, degrees of freedom $(\mathrm{df})=584, \mathrm{RMR}=0.039, \mathrm{GFI}=0.780$, $\mathrm{AGFI}=0.749, \mathrm{IFI}=0.84, \mathrm{CFI}=0.839$, RMSEA $=0.072$ ). Each construct has good convergent and discriminant validity (the factor loadings greater than 0.5 , square root of AVE greater than inter-construct correlations).

\subsection{Hypotheses Testing}

For testing $\mathrm{H} 1$, we conducted the multiple regression analysis. As shown in Table 1, online promotions (price discounts; buy more save more; discount coupons; flash sale) positively impacted on online impulsive buying behavior $\left(\beta_{1}=0.372, \beta_{2}=0.321, \beta_{3}=0.255, \beta_{4}=0.364\right)$, supporting $H 1$.

Table 1: Result of Regression Analysis for Online Promotions on Online Impulsive Buying Behavior

\begin{tabular}{ccccccc}
\hline $\begin{array}{c}\text { Independent } \\
\text { Variable } \\
\text { (Online }\end{array}$ & $\begin{array}{c}\text { Dependent } \\
\text { Variable }\end{array}$ & $\beta$ & $\mathrm{T}$ & Sig. & $\Delta \mathrm{R}^{2}$ & $\mathrm{~F}$ \\
Promotions) & & 0.37 & 7.27 & 0.00 & 0.13 & 52.91 \\
\hline Price discounts & & $2^{1}$ & 4 & 0 & 6 & 7 \\
Buy More, Save & Online & 0.32 & 6.05 & 0.00 & 0.09 & 36.70 \\
More & Impulsive & $1^{2}$ & 9 & 0 & 8 & 6 \\
Discount & Buying & 0.25 & 5.05 & 0.00 & 0.06 & 25.56 \\
Coupons & Behavior & $5^{3}$ & 6 & 0 & 9 & 1 \\
Flash Sale & & 0.36 & 6.92 & 0.00 & 0.12 & 47.97 \\
& & 44 & 6 & 0 & 5 & 6 \\
\hline
\end{tabular}

$\mathrm{H} 2$ and $\mathrm{H} 3$ were testing mediation with regression analysis. In Table 2 and 3 , all VIF values were minor than 10 that meant no collinear combination. As Table 2, after adding perceived value to the analysis, the $\beta$ between online promotions and on online impulsive buying behavior decreased (e.g., price discounts $=\beta_{1}$ from 0.372 to 0.142 ) and $\Delta R^{2}$ were $0.259-0.277$. Thus, $\mathrm{H} 2$ was partially supported.

Table 2: Result of Regression Analysis for Examining Mediating Effect of Perceived Value

\begin{tabular}{cccccccc}
\hline $\begin{array}{c}\text { Independent } \\
\text { Variable }\end{array}$ & $\begin{array}{c}\text { Dependent } \\
\text { Variable }\end{array}$ & $\beta$ & $\mathrm{T}$ & Sig. & $\Delta \mathrm{R}^{2}$ & $\mathrm{~F}$ & $\mathrm{VIF}$ \\
\hline Price discounts & Online & 0.14 & 2.5 & 0.0 & & & \\
Perceived & Impulsive & $2^{1}$ & 62 & 11 & 0.2 & 62.6 & 1.3 \\
Value & Buying & 0.49 & 7.8 & 0.0 & 72 & 03 & 86 \\
& Behavior & 0 & 98 & 00 & & & \\
\hline Buy More, Save & Online & 0.11 & 2.1 & 0.0 & & & \\
More & Impulsive & $3^{2}$ & 24 & 34 & 0.2 & 61.2 & 1.2 \\
Perceived & Buying & 0.51 & 8.7 & 0.0 & 68 & 12 & 46 \\
Value & Behavior & 9 & 86 & 00 & & & \\
\hline Discount & Online & 0.10 & 2.0 & 0.0 & & & \\
Coupons & Impulsive & $2^{3}$ & 11 & 40 & 0.2 & 58.5 & 1.2 \\
Perceived & Buying & 0.55 & 9.2 & 0.0 & 59 & 79 & 68 \\
Value & Behavior & 2 & 22 & 00 & & & \\
\hline Flash Sale & Online & 0.15 & 2.9 & 0.0 & & & \\
Perceived & Impulsive & 74 & 10 & 04 & 0.2 & 63.8 & 1.2 \\
Value & Buying & 0.49 & 8.3 & 0.0 & 77 & 95 & 70 \\
& Behavior & 5 & 52 & 00 & & & \\
\hline
\end{tabular}

As Table 3, after adding positive emotion to the analysis, the $\beta$ between online promotions and on online impulsive buying behavior decreased (e.g., price discounts $=\beta_{1}$ from 0.372 to 0.202 ) and $\Delta \mathrm{R}^{2}$ were $0.295-0.313$. Thus, positive emotion partially mediated between online promotions and on online impulsive buying behavior. The analysis of discount coupons, a previously significant was no longer significant $(\mathrm{P}=0.143)$. This was complete mediation. Thus, $\mathrm{H} 3$ was partially supported.

Table 3: Result of Regression Analysis for Examining Mediating Effect of Positive Emotion

\begin{tabular}{cccccccc}
\hline $\begin{array}{c}\text { Independent } \\
\text { Variable }\end{array}$ & $\begin{array}{c}\text { Dependent } \\
\text { Variable }\end{array}$ & $\beta$ & $\mathrm{T}$ & Sig. & $\Delta \mathrm{R}^{2}$ & $\mathrm{~F}$ & $\mathrm{VIF}$ \\
\hline Price discounts & Online & 0.20 & 4.0 & 0.0 & & & \\
Positive & Impulsive & 21 & 94 & 00 & 0.3 & 75.9 & 1.1 \\
Emotion & Buying & 0.51 & 9.2 & 0.0 & 13 & 58 & 64 \\
& Behavior & 3 & 04 & 00 & & & \\
\hline Buy More, Save & Online & 0.13 & 2.6 & 0.0 & & & \\
More & Impulsive & 42 & 36 & 09 & 0.2 & 69.1 & 1.1 \\
Positive & Buying & 0.54 & 9.5 & 0.0 & 97 & 24 & 74 \\
Emotion & Behavior & 1 & 62 & 00 & & & \\
\hline Discount & Online & 0.07 & 1.4 & 0.1 & & & \\
Coupons & Impulsive & 03 & 66 & 43 & 0.2 & 65.7 & 1.1 \\
Positive & Buying & 0.56 & 9.9 & 0.0 & 87 & 8 & 76 \\
Emotion & Behavior & 6 & 20 & 00 & & & \\
\hline \multirow{2}{*}{ Flash Sale } & Online & 0.14 & 2.8 & 0.0 & & & \\
Positive & Impulsive & 94 & 18 & 04 & 0.2 & 69.8 & 1.2 \\
Emotion & Buying & 0.52 & 8.9 & 0.0 & 95 & 16 & 59 \\
& Behavior & 3 & 49 & 00 & & & \\
\hline
\end{tabular}

As shown in Table 4, an interaction term was putting into the regression model. The results of M3 showed that online reviews cannot significantly moderate the effect of online promotions on online impulsive buying behavior $(\beta=-0.037, p>0.05)$. Thus, $\mathrm{H} 4$ was not supported.

Table 4: Result of Hierarchical Regression Analysis (Online Reviews as a Moderator)

\begin{tabular}{|c|c|c|c|c|c|c|c|c|}
\hline & $\begin{array}{c}\text { Independent } \\
\text { Variable }\end{array}$ & $\begin{array}{c}\text { Dependent } \\
\text { Variable }\end{array}$ & $\beta$ & $\mathrm{T}$ & Sig. & $\begin{array}{c}\Delta \mathrm{R} \\
2\end{array}$ & $\mathrm{~F}$ & VIF \\
\hline $\begin{array}{c}M \\
1\end{array}$ & $\begin{array}{c}\text { Online } \\
\text { Promotions }\end{array}$ & $\begin{array}{c}\text { Online } \\
\text { Impulsive } \\
\text { Buying } \\
\text { Behavior } \\
\end{array}$ & $\begin{array}{l}0.4 \\
71\end{array}$ & $\begin{array}{l}7.7 \\
72\end{array}$ & $\begin{array}{l}0.0 \\
00\end{array}$ & $\begin{array}{l}0.1 \\
53\end{array}$ & $\begin{array}{c}60.3 \\
97\end{array}$ & $\begin{array}{l}1.0 \\
00\end{array}$ \\
\hline $\begin{array}{l}M \\
2\end{array}$ & $\begin{array}{c}\text { Online } \\
\text { Promotions } \\
\text { Online } \\
\text { Reviews } \\
\end{array}$ & $\begin{array}{c}\text { Online } \\
\text { Impulsive } \\
\text { Buying } \\
\text { Behavior } \\
\end{array}$ & $\begin{array}{l}0.1 \\
13 \\
0.7 \\
71 \\
\end{array}$ & $\begin{array}{c}1.8 \\
65 \\
11 . \\
251 \\
\end{array}$ & $\begin{array}{c}0.0 \\
63 \\
0.0 \\
00 \\
\end{array}$ & $\begin{array}{l}0.3 \\
87\end{array}$ & $\begin{array}{l}105 . \\
053\end{array}$ & $\begin{array}{l}1.3 \\
81\end{array}$ \\
\hline $\begin{array}{c}\text { M } \\
3\end{array}$ & $\begin{array}{c}\text { Online } \\
\text { Promotions } \\
\text { Online } \\
\text { Reviews } \\
\\
\text { Online } \\
\text { Promotions* } \\
\text { Online } \\
\text { Reviews }\end{array}$ & $\begin{array}{l}\text { Online } \\
\text { Impulsive } \\
\text { Buying } \\
\text { Behavior }\end{array}$ & $\begin{array}{c}- \\
0.0 \\
37\end{array}$ & $\begin{array}{l}- \\
0.4 \\
20\end{array}$ & $\begin{array}{l}0.6 \\
75\end{array}$ & $\begin{array}{l}0.3 \\
86\end{array}$ & $\begin{array}{c}69.9 \\
17\end{array}$ & $\begin{array}{l}1.3 \\
82\end{array}$ \\
\hline
\end{tabular}

\section{Conclusions}

The main contribution of this paper is through the questionnaire survey and regression analysis to demonstrate the impact of online promotions on online impulsive buying behavior, mediated by perceived value and positive emotion. This paper proposes a four-dimensional model of online promotions. Multiple regression analysis showed that "price discounts" have the biggest impact on impulsive purchase, the second is "flash sale", 
the third is "buy more save more", and the last is discount coupons. Furthermore, the results showed that online promotions had significantly positive impacts on online impulsive buying behavior, consistent with the works of Lai (2017).

Perceived value and positive emotion both played a mediating role between online promotions and online impulsive buying behavior respectively. Online reviews did not play a moderating role. Through the empirical research, the paper found that online promotion activities could positively affect consumers' perceived value, capture their attention, and increase their impulsive purchase.

Eventually, after the positively mediating role of positive emotion was considered, this paper suggested that online shopping enterprises shall conduct massive online promotions activities in stimulating consumer enthusiasm and passion so as to lead to the results of impulsive buying behavior.

\section{References}

[1] Bansal, H. S., \& Voyer, P. A. (2000). Word-of-mouth processes within a services purchase decision context. Journal of Service Research, 3(2), 166177.

[2] Beatty, S. E., \& Ferrell, M. E. (1998). Impulse buying: Modeling its precursors. Journal of Retailing, 74(2), 169-191.

[3] Campbell, L., \& Diamond, W. D. (1990). Framing and Sales Promotions: The Characteristics of a "Good Deal ". Journal of Consumer Marketing, 7(4), 25-31.

[4] Chan, K. K. (1996). Chinese viewers' perception of informative and emotional advertising. International Journal of Advertising, 15(2), 152166.

[5] China Internet Network Information Center (CNNIC) Statistical Reports (2017). https://cnnic.com.cn/IDR/ReportDownloads/
[6] Jeffrey, S. A., \& Hodge, R. (2007). Factors influencing impulse buying during an online purchase. Electronic Commerce Research, 7(3-4), 367379.

[7] Lai, J. (2017). The comparative research on online impulsive buying behaviour between the UK and China. Journal of Residuals Science and Technology, 14(S1), S119-S124.

[8] Madhavaram, S. R., \& Laverie, D. A. (2004). Exploring impulse purchasing on the internet. in NA-Advances in Consumer Research Volume 31, eds. Kahn and Luce, Valdosta, GA: Association for Consumer Research, 59-66.

[9] Mathwick, C., Malhotra, N. K., \& Rigdon, E. (2002). The effect of dynamic retail experiences on experiential perceptions of value: an Internet and catalog comparison. Journal of Retailing, 78(1), 51-60.

[10] Oh, H. (2000). The effect of brand class, brand awareness, and price on customer value and behavioral intentions. Journal of Hospitality \& Tourism Research, 24(2), 136-162.

[11] Park, D. H., \& Kim, S. (2008). The effects of consumer knowledge on message processing of electronic word-of-mouth via online consumer reviews. Electronic Commerce Research and Applications, 7(4), 399-410.

[12] Park, D. H., Lee, J., \& Han, I. (2007). The effect of online consumer reviews on consumer purchasing intention: The moderating role of involvement. International Journal of Electronic Commerce, 11(4), 125148.

[13] Park, M., \& Lennon, S. J. (2009). Brand name and promotion in online shopping contexts. Journal of Fashion Marketing and Management: An International Journal, 13(2), 149-160.

[14] Swinyard, W. R. (1993). The effects of mood, involvement, and quality of store experience on shopping intentions. Journal of consumer Research, $20(2), 271-280$.

[15] Yoo, C., Park, J., \& MacInnis, D. J. (1998). Effects of store characteristics and in-store emotional experiences on store attitude. Journal of Business Research, 42(3), 253-263. 